\title{
THE INFLUENCE OF OWNERSHIP STRUCTURE ON THE DEVELOPMENT OF INTERNATIONAL ACTIVITIES OF INTERNATIONAL BUSINESS ENTITIES
}

\author{
Olga Sunigovets ${ }^{1}$
}

\begin{abstract}
The purpose of the article is to generalize the existing views on ensuring the effectiveness of international business entities in the context of globalization trends and the implementation of the tasks of domestic companies to enter international markets. Systematization of problems of international business development on the basis of the research of the impact of structural aspects in ensuring economic development, with special emphasis on studying the development of the ownership structure of international business in the formation of the foundations of sustainable economic growth. Methodology. The study is based on comparing trends in the development of international business of countries, processing the results of studying the issues of the topic by domestic and foreign economists, domestic and foreign literature, statistical data, the results of analytical studies of rating agencies, international organizations. In the process of research, the method of theoretical generalization and comparison, and general scientific research methods were used, mainly, analysis, synthesis, abstraction. The information basis of the research consisted of the works of domestic and foreign scientists on the problems of the theory of international business, international economic relations, international management, and international corporate governance of international business. The results of the research showed that the modern conditions for conducting international business were changing dynamically, which required the development of international business entities special improvement of existing approaches to management in accordance with the conditions of globalization, manifestation of innovative development and striving for openness as the best way of modern coexistence. The country's position in the world economic system is determined by the structure of the economy. Practical implications. Thus, the structure of the economy determines the possibilities of economic development, the ownership structure is an important aspect in ensuring the efficiency of international business. In the context of globalization, corporate governance is seen as a tool for development and needs improvement for the enterprises to enter into international markets. The ownership structure is able to determine the innovative potential of enterprises in world markets. Value/originality. The identified current trends in the development of structural relationships of the economy based on the generalization of research on structural interdependencies in creating the preconditions for sustainable economic development allows to determine the basis for the actions of international business in the globalization and manifestations of innovative economy more objectively. The special value of the work lies in a more detailed study of the ownership structure in ensuring the efficiency of international business and the effects of globalization, which determines the main directions of improving Ukrainian enterprises, their organizational and legal forms of doing business to ensure compliance with international business principles and access to international markets.
\end{abstract}

Key words: Globalization and innovation development, economic structure, ownership structure, international business, business efficiency, corporate governance.

JEL Classification: O30, F43, G32, G34, F23

\section{Introduction}

Globalization exacerbates international competition. It determines the increase in labor productivity as a result of rationalization of production at the global level and the spread of advanced technologies, continuous introduction of innovations worldwide. Such trends have determined the need for the formation of a new

\footnotetext{
Corresponding author:

${ }^{1}$ National Technical University «Kharkiv Polytechnic Institute», Ukraine.

E-mail: oms.ukr.kpi@gmail.com

ORCID: https://orcid.org/0000-0003-1623-5798
} 
system of world economic structures, the principles of development of the regulatory system, the global business philosophy.

The effectiveness of modern companies, based on the peculiarities of their organization and operation, is determined by the coordination of actions in both domestic and global markets. State regulation of concentration and development of property can smooth out contradictions.

The modern economy is called the corporate economy. The income of large corporations is many times higher than the income of many countries. Corporate governance in the context of globalization is seen as a powerful source of economic growth. In the context of economic globalization, the problems of corporate governance are exacerbated. The development of the corporate sector of the economy is determined by transnationalization, the access to the world level of large corporations, small and medium-sized companies, the interpenetration of corporate governance models, improving corporate relations as a result of employee participation in the ownership, profits and management of the corporation, institutionalization in accordance with the basic principles of corporate governance, the implementation of corporate social responsibility.

Thus, development determines the improvement of the institutional environment of doing business, which requires detailed research.

The purpose of the article is to study the main aspects of ensuring the effectiveness of international business in the face of globalization, which will ensure the development of international business to globalization, improving corporate governance practices in accordance with global norms and rules.

\section{The structure of economic systems in the context of globalization}

The structure of the economy makes it possible to establish its proportions, which determine its state, impact on social aspects in society, the country's position in the world economic system.

The structural model of the economy is formed by a set of different economic proportions. The imbalance of these proportions leads to macroeconomic disproportion and the crisis in the structure of the country's economy. The constituent elements of the structure of the economy are different structures, reproductive, industrial, institutional, territorial, foreign economic, sectoral, technological, social.
The institutional structure determines the conditions for the functioning and development of economic entities, on the basis of which there are property rights, the legal regime of resource use, taxation, methods of income generation, etc. The main proportions of the institutional structure are studied by the structure of ownership, competition, management, legal structure. The ratio of exports and imports of goods, services, technologies, capital, etc., the structure of exports and imports determine the proportions of the foreign economic structure.

Correspondence of the national economy to the tendencies of scientific and technical development of the countries of the world, a share of the made production or the services corresponding to this or that techno-economic paradigm characterize technological structure.

The generalizations as to the efficiency of the structure of the national economy and those that characterize the state of economic and social development of the country are the proportions of the social structure.

\section{Ownership structure and international activities of international business entities}

Interstate proportions form quantitative relations between the national industries of different countries. Various options for achieving proportionality in economic development are proposed. The structure of ownership is of great importance for the economy, determining the nature and essence of the processes of production, consumption and distribution. State, natural and legal persons' property is recognized. The organic combination of all of them in the economy creates opportunities to achieve high rates of economic growth.

The ownership structure reflects the nature of the existing relationship between the objects and the subjects of ownership and is specific to each country. Most likely, all countries are a society with a mixed economy. The types of ownership of a mixed economy are private, joint equity, joint compatible. Now it is not an individual but a joint share form (of share capital, financial capital) that prevails. The state seeks to regulate at the legislative level the relationship of ownership, disposal and use of property (Samuelson, 1989).

The modern structure of the economy is characterized by shadow property relations, this is a set of unregulated and unaccounted for at 
the legislative level of economic relations that take proceed outside the legal field. In developed countries, the basis of the economy is small enterprises with private ownership of the means of production. In Ukraine, business entities include legal entities and sole proprietors. The change in the number of subjects by organizational and legal forms of management is shown in Figure 1 and Figure 2.

Creating conditions for the realization of property rights, which combines the interests of social stability, justice and active economic development, is the main task of forming a modern property structure in Ukraine. Due to the need to preserve natural resources, improve the living environment, solve social problems and take into account the scarcity and impact on the environment, the need for minimum consumption of natural resources is determined. In solving such problems, preference is given to planning mechanisms and the predominant form of ownership is recognized as state property.

In the field of meeting personal and group needs, the private form of ownership will prevail, as it provides higher productivity and this determines its predominant use. The economic factor is significantly reduced under the influence of the achievements of STP. The formation of the world market and services intensifies competition, promotes the formation of transnational corporations, which determines the transition of private property to a new level.

Globalization takes place within private property, strengthening its position. State property has significant potential in the context of globalization to address the challenges of cooperation. The optimal value of the share of state property according to the results of research under the conditions that have been most favorable for state property is called at the level of $22 \%$, this figure is close to that of Sweden $-20.5 \%$. The ratio is not a constant value. This ratio changes under the influence of various factors. The greater proportion of private property determines its higher efficiency.

The factors influencing the studied relationships are characterized as difficult to define and measure, these factors have an indirect manifestation of influence, while changing the gap in the effectiveness of these forms of property management. The main factors are:

- rate of return on capital;

- degree of automation of production processes;

- educational, moral and ethical level of the population;

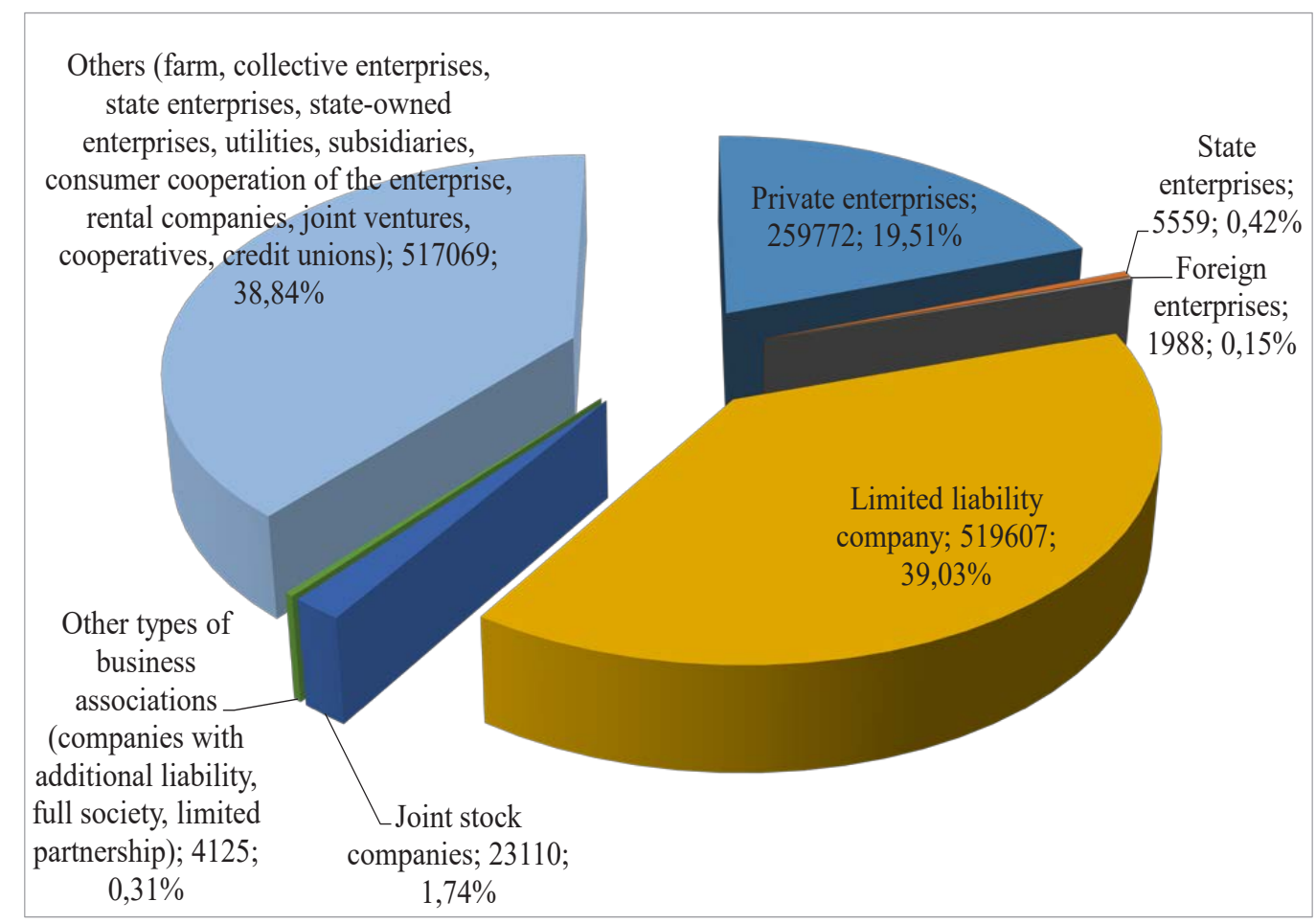

Figure 1. Number of legal entities by organizational and legal forms of management as of the beginning of $\mathbf{2 0 1 5}$

Source: developed by the author on the basis of (Derzhavna sluzhba statystyky Ukrajiny) 


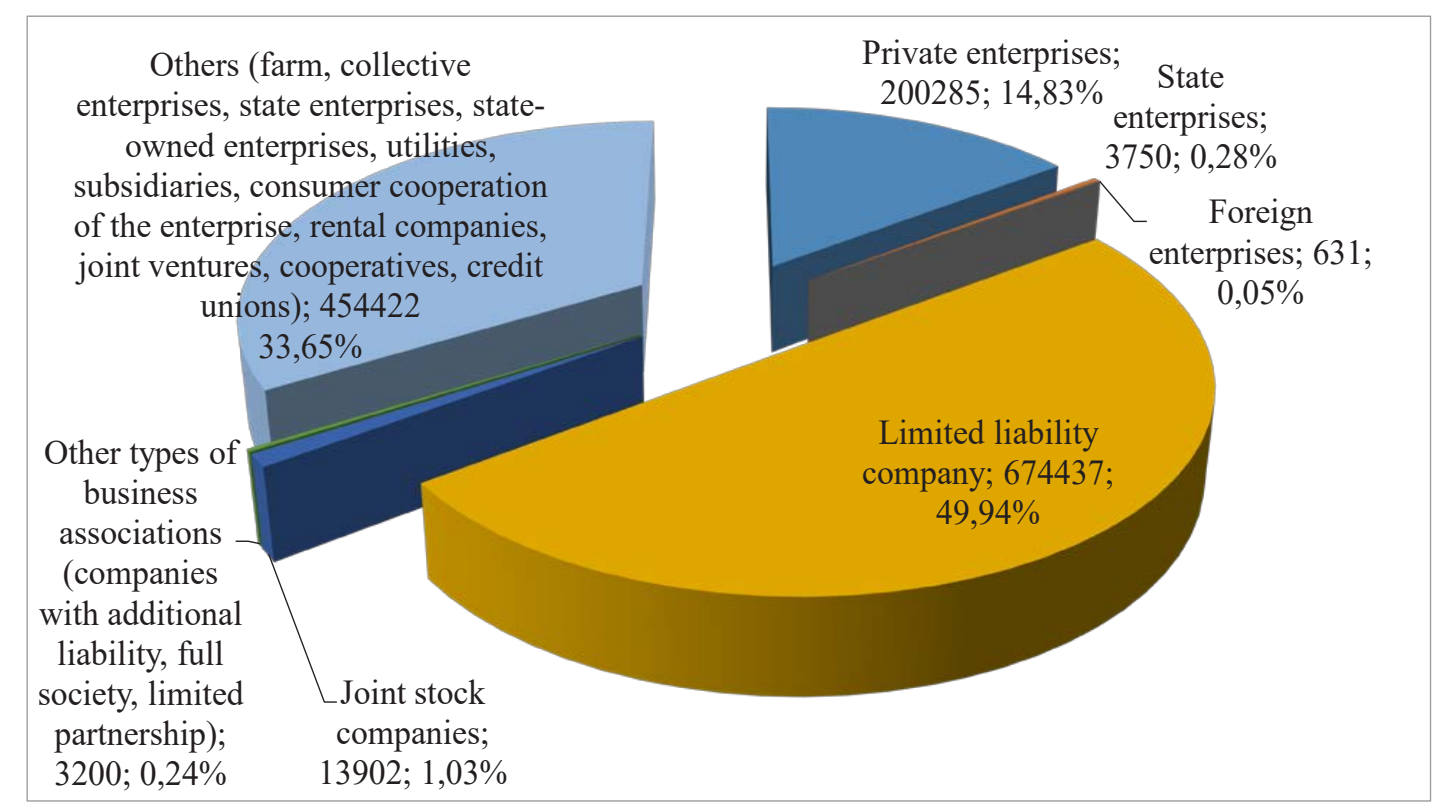

Figure 2. Number of legal entities by organizational and legal forms of management as of the beginning of 2020

Source: developed by the author on the basis of (Derzhavna sluzhba statystyky Ukrajiny)

- importance of non-economic needs of society (ecology, space, etc.).

The ratio under consideration affects socioeconomic efficiency; there is a ratio at which the maximum effect is ensured.

The private initiative responds more quickly to the request, satisfies them better and more economically. Private property ensures the development and implementation of scientific and technical progress more successfully and this provides its efficiency advantage. Any factors that reduce the return on capital, respectively, reduce the interest in doing business.

Thus, the high level of production efficiency is associated with a relatively small share of state ownership and a significant share of highly profitable private households. Highly efficient production is also due to the large share of small and mediumsized firms, which provides flexibility, stability and maneuverability to socio-economic processes. The growth of joint ventures and the share of state participation in them should be recognized as an attempt to combine the advantages of centralized and private enterprise approaches.

\section{International regulation of corporate governance}

Modern manifestations of globalization have been identified in:
- increase of the scale of international trade;

- information development;

- growth of international mergers and acquisitions; - growth of scales of activity and companies with the participation of foreign capital;

- strengthening the role of large multinational corporations in the world economy;

- formed world market.

In modern conditions, attempts have been made to regulate the activities of large corporations and approaches to their management. Bringing uniformity to the understanding of corporate governance in the international market can have some success. Such a well-defined system of relationships is created and operates to ensure maximum efficiency, attract investment, fulfill legal and social obligations (Jensen \& Fama, 1983).

Regulation of corporate governance is implemented through the development of standards, namely:

- corporate governance quality criteria developed by various rating agencies;

- financial reporting standards;

- requirements of stock exchanges;

- codes and principles of corporate governance.

Many international organizations are developing corporate governance standards, namely the Organization for Economic Co-operation and Development, the World Bank, the International 
Monetary Fund and a number of European organizations.

Normative models are based on OECD recommendations on corporate governance principles. The demand for information and e-services in management is not clearly defined, according to normative models for stakeholders it is better to be more aware of management (McKinsey \& Company, 2002). Thus, it requires the development of tools that use information and communication technologies, the companies' costs required to provide feedback to its stakeholders.

There are the following types of assessments of the effectiveness of corporate governance:

- corporate governance rating;

- investment rating;

- credit rating.

The most famous rating agencies in the world are Standard \& Pools, Moody's, Fitch Ratings Morningstar. It is believed that national rating agencies can better take into account local specifics.

The final corporate governance rating of the well-known international rating agency Standard \& Pools is determined on the basis of a weighted assessment of the performance of companies in the following four main groups:

- shareholder rights;

- activities of management and control bodies;

- disclosure of information;

- compliance with the interests of other stakeholders, corporate social responsibility.

The achieved level of corporate governance of the company sets one of the four rating classes A, B, C, $D$. The first three classes of the rating with the help of gradation allow you to compare companies of one rating.

The GAMMA rating reflects the relative pros and cons of a particular company's corporate governance practices in terms of protecting investors from possible loss of value or lost opportunities to create value due to shortcomings in the corporate governance system.

The main components of corporate governance rating are shareholder influence, shareholder rights, transparency, audit and risk management system, the effectiveness of the Board of Directors, the strategic process and the reward system. The rating criteria are based on a number of international codes of corporate governance, research, individual company practice and S\&P experience.

Given the growing interest and importance of adhering to the advanced principles of corporate governance, regular monitoring of enterprises and attracting more participants to the ranking are important. This will improve the practice of corporate governance of the Ukrainian enterprises, and the increase in the number of participants in the rating will also be evidence of the formation of a stable, civilized stock market. The standard of corporate governance is implemented on a voluntary basis. The driving factor in achieving high standards of corporate governance is the concomitant increase in the investment attractiveness of companies

The methodology for assigning a rating to enterprises builds an analytical process in accordance with global criteria. Credit ratings are more an assessment of a legal entity's ability and willingness to repay its debt obligations, the existing criteria are aimed at determining the characteristics of its own creditworthiness and the issuer's credit rating for a particular company.

S\&P's credit rating provides assessments of the business risk profile, the company's financial risk profile, thus determining the base level of the rating, and other factors, additional rating factors may change the base level of the rating and these factors, or as they are called modifiers, reflect business diversification analysis, capital structure, financial policy, liquidity and management, corporate governance.

Corporate governance ratings carry a burden not only on the counterparties, but also on society as a whole, the main component is a high level of transparency and the development of mechanisms and criteria for reconciling numerical interests. Compliance with these criteria and the conditions of globalization is also facilitated by international agreements in various areas of the economy and business.

\section{Transparency of companies in the context of globalization}

Information transparency of companies, as a characteristic of the quality of corporate governance, is a factor in shaping the value of companies.

The issue of transparency calls for even more attention to the development of the concept of e-corporate governance. Electronic corporate governance is defined as the provision of internal and external interactions in the company, aimed at maintaining the balance of interests between stakeholders through the introduction of information and communication technologies. The 
development of e-corporate governance can change existing approaches to solving corporate governance problems. The study of national models of corporate governance should be conducted based on the tools of the new institutional economy. Existing searches are based on the theory of the firm.

In addition, it is necessary to identify models that are more consistent with the development of the modern economy in the context of globalization and with the manifestations of convergence of existing models.

Disclosure issues and transparency are the focus of rating, analytical and consulting agencies such as Hallvarsson \& Halvarsson, Standart \& Poor's. Increasing the transparency of companies will help to increase the efficiency of the capital market.

Electronic corporate governance in itself can increasethetransparencyoftheenterprise.Principles and tasks for improving the quality of management through the effective use of information due to information and communication technologies are being developed (Okot-Uma, 2001).

The main content of the requirements is determined by increasing the availability of information and services, openness and accountability of management, public involvement in the management process.

Recognizing that any classification based on concentration of ownership is conditional, the ownership structure can be very complex and the division into dispersed and concentrated ownership structures is possible only with great restrictions, we should talk about the prevalence of firms with dispersed and concentrated ownership in countries.

Usually, countries with a high level of shareholder protection are characterized by firms with dispersed ownership, while countries with a low level of protection are dominated by another model of firms.

From the point of view of the ownership concentration factor, two basic models are defined: companies with dispersed ownershipand companies with concentrated ownership. This division has another basis, respectively distinguishing between market-oriented and bank-oriented models. In the market model, the capitalization of the company is determined by the stock market, in the banking model, most corporations are managed by the bank and the main form of financing is a bank loan.

The market-oriented model makes strict requirements for the provision and disclosure of information.
Serious shortcomings in the domestic practice of corporate governance have been identified:

- the formal nature of the implementation of corporate procedures;

- weakness of the risk management system;

- insufficient role of the board of directors in the implementation of corporate governance;

- violation of the of minority shareholder rights.

The factors that determine the effectiveness of corporate governance include:

- level of ownership concentration;

- personnel policy;

- concentration on key competencies;

- information support;

- features of cultural traditions;

- development of legislative and institutional environment.

In international economic relations, the protection of property rights is less perfect than in the leading industrialized countries. Common hierarchical structures are created.

The formation of corporate ownership depends on the involvement of state-owned enterprises, the development of holding companies and the formation of a mixed ownership. Each model of corporate governance has its own control mechanisms, they are determined by the structure of the corporation's ownership, the number of shareholders.

\section{Conclusions}

The main goal of property reforms is to change the behavior and increase the efficiency of enterprises. The process of redistribution of shares took place from employees to managers, from insiders to external shareholders and from the state to nonstate shareholders. Managers of enterprises are the dominant group of owners, the participation of external shareholders is less significant.

The formation of a coalition of large owners is more effective due to the possibility of limiting expropriated behavior and mutual complementarity. Such a more balanced and less asymmetric configuration of ownership helps to maximize the market value of companies. The growing integration of financial markets, the globalization of commodity markets, the convergence of legal and institutional norms, and the open exchange of information have determined the processes of convergence of national models of corporate governance.

This tendency occurs in the direction of marketoriented model, companies with dispersed 
property, reduction of concentration of property, introduction on the open market of a part of large blocks of shares by the entrepreneurs who inherited business of big holders.

Necessary changes in the ownership structure, information disclosure system, legal and economic factors are now due to the development of corporate governance. Enterprises that can adapt corporate governance to their own business models will gain a significant competitive advantage. The introduction of corporate governance standards by small and medium-sized companies can ensure success in competition in the global market.

The promotion of civilized principles of corporate governance should be recognized as a long-term strategic goal of international business entities. One cannot ignore the development of the need for longterm goal-setting, expanding the space of corporate relations, taking into account the interests of all key, not only traditional, stakeholders.

Increasing business transparency, introducing a corporate social responsibility system with a predominance of companies of entrepreneurial composition, ensuring a real delineation of ownership and management, improving the indicators of investment in fixed assets and activity in the IPO market, which is a significant problem for Ukraine, can improve and ensure compliance with international business development trends in the context of globalization. The practice of corporate governance requires the application of adequate to the requirements of global norms and rules.

\section{References:}

Derzhavna sluzhba statystyky Ukrajiny (2020). Statystychna informatsiia. Available at: http://www.ukrstat.gov.ua

Jensen, M., \& Fama, E. (1983). Separation of ownership and control. Journal of Law and Economics, vol. 26, issue 2, pp. 301-325. doi: https://dx.doi.org/10.1086/467037z

McKinsey \& Company (2002). Governance is unceasingly at the heart of investment decisions, new McKINSEY Survey shows. Investors Eager for Greater Accounting Disclosure, Other Broad Reforms. Available at: http://www.mckinsey.com/governance

Okot-Uma, R. (2001). Electronic Governance: Re-inventing Good Governance. London: Common-wealth Secretariat. Available at: https://citeseerx.ist.psu.edu/viewdoc/download? doi=10.1.1.197.6576\&rep=rep1\&type $=$ pdf

Samuelson, P. (1989). Economics (13th ed.). New York: McGraw-Hill, 837 p. Available at: https://archive.org/details/economicsintrodu00paul/page/n10/mode/lup 